Research Article

\title{
Toxin Production and Resistance of Staphylococcus Species Isolated from Fermented Artisanal Dairy Products in Benin
}

\author{
Majoie Géroxie Tohoyessou, ${ }^{1}$ Wassiyath Mousse, ${ }^{1}$ Haziz Sina $\left(\mathbb{D},{ }^{1}\right.$ Fernique Kona, ${ }^{2}$ \\ Tania Azanghadji, ${ }^{1}$ Nathalie Guessennd, ${ }^{2}$ Farid Baba-Moussa, ${ }^{3}$ Thomas Dadie, ${ }^{4}$ \\ Adolphe Adjanohoun, ${ }^{5}$ and Lamine Baba-Moussa $\mathbb{D D}^{1}$ \\ ${ }^{1}$ Laboratory Biology and Typing Molecular in Microbiology, Faculty of Science and Technology, University of Abomey-Calavi, \\ 05 BP 1604, Cotonou, Benin \\ ${ }^{2}$ Antibiotics, Natural Substances and Surveillance of Resistance of Microorganisms to Anti-Infective Unit (ASSURMI), \\ Institute Pasteur of Ivory Coast, 01 BP 490, Abidjan 01, Côte d'Ivoire \\ ${ }^{3}$ Laboratory of Microbiology and Food Technology, Faculty of Science and Technology, University of Abomey-Calavi, \\ ISBA-Champ de Foire, 01 BP 526, Cotonou, Benin \\ ${ }^{4}$ Laboratory of Biotechnology and Food Microbiology, University Nangui Abrogoua, 02 B.P. 801, Abidjan 02, Côte d'Ivoire \\ ${ }^{5}$ Benin National Institute of Agricultural Research, Cotonou, Benin
}

Correspondence should be addressed to Lamine Baba-Moussa; laminesaid@yahoo.fr

Received 27 June 2020; Revised 1 September 2020; Accepted 13 October 2020; Published 28 October 2020

Academic Editor: Giovanna Franciosa

Copyright (c) 2020 Majoie Géroxie Tohoyessou et al. This is an open access article distributed under the Creative Commons Attribution License, which permits unrestricted use, distribution, and reproduction in any medium, provided the original work is properly cited.

\begin{abstract}
Staphylococcus species are considered as one of the major pathogens causing outbreaks of food poisoning. The aim of this work was to assess the toxinogenic and antibiotic susceptibility profiles of the strains of Staphylococcus spp isolated from three types of fermented dairy products (yoghourt, millet dêguê, and couscous dêguê). The isolation of the Staphylococcus strains was performed on selective media, and their identification was done using biochemical and molecular methods. The susceptibility at 15 antibiotics tested was assessed using the disc diffusion method. The immunodiffusion method was used to evaluate the toxin (luk-E/D, luk-S/ F, ETA, and ETB) production. Biofilm formation was qualitatively researched on microplates. Less than half (42.77\%) of the collected samples were contaminated with Staphylococcus spp. The yoghourt and millet dêguê samples collected in the afternoon were more contaminated than those collected in the morning. The S. aureus, S. capitis, and S. xylosus strains, respectively, were the most present. S. aureus was the only coagulase-positive species identified in our samples. The highest resistance to antibiotics was observed with penicillin (100\%) irrespective of the nature of the sample. S. aureus strains were highly (71.4\%) resistant to methicillin. The S. aureus strains were the most biofilm-forming (27.6\%), followed by S. capitis strains. Panton and Valentine's leukocidin (luk-S/F) was produced by only S. aureus strains at a rate of $8.33 \%$. Only coagulase-negative Staphylococcus (CNS) produced Luk-E/D. The high rates of Staphylococci contamination indicate bad hygiene quality during the production and distribution of dairy products. It is, therefore, necessary to improve the quality of fermented milk products.
\end{abstract}

\section{Introduction}

Milk and its derivative products are very important in children's diets. Fluid milk is a single food providing calcium, potassium, phosphorus, lactose, casein phosphopeptide, and vitamin D in children [1]. Thus, dietary calcium comes mainly from dairy products such as milk, yoghourt, and cheese [2,3] as well as other dairy products [4]. In West African countries, the most consumed are dèguè (millet and couscous), yoghourt, gappal, and tchobal [5]. Over the last few years, food poisoning and food safety have become very topical subjects, drawing much public concern [6]. Foodborne infections are very common and are related to the consumption of many foods including drinks sold in 
catering and contaminated with certain bacteria or their toxins. Milk products derived from dairy cows milk can harbor a variety of microorganisms [7] and can be important sources of foodborne pathogen [8]. Various bacteria strains (Clostridium botulinum, Clostridium perfringens, Campylobacter, Escherichia coli, Salmonella, and Staphylococcus aureus) can cause food poisoning [9]. Among the mentioned bacteria, Staphylococcus aureus is a major bacterial pathogen responsible for a broad and divergent range of human and animal infections, including toxin-mediated foodborne diseases $[10,11]$. S. aureus is reported to be one of the important causes of bovine mastitis and one of the most cost-intensive diseases in the dairy industry [12-14].

To control bacterial infections, the uncontrolled use of antibiotics by self-medication has select resistance bacteria. Unfortunately, most of the antibiotics known to date face bacterial resistance [15]. It was thus reported that methicillin-resistant $S$. aureus (MRSA) can form a powerful biofilm and easily colonize the mucous membranes, which is one of the reasons causing chronic, recurrent, or invasive infections [16]. Their capacity to adhere and form biofilms on the surface of milk processing equipment could contribute to be a source of $S$. aureus contamination of dairy production [17, 18]. Recently, MRSA strains have been detected in various types of food products, including meat products, raw products, milk, and dairy products all over the world [19-21].

Resistance makes the treatment of bacterial infections through conventional antibiotics difficult. In addition, $S$. aureus is often associated with a wide variety of virulence factors such as the production of Panton and Valentine's leukocidin (PVL) and heat-resistant staphylococcal enterotoxins which, when ingested, can cause gastrointestinal disorders [22]. Dairy products generally harbor enterotoxigenic $S$. aureus strains that can induce foodborne intoxications in humans $[23,24]$. The produced enterotoxins are reported to cause abdominal cramps, nausea, emesis, and eventually diarrhea $[25,26]$.

They are increasingly diagnosed in Benin where collective catering, which has become a phenomenon of modern societies due to its nutritional and socioeconomic importance, has considerably increased in recent years [27]. In view of the many cases of food poisoning caused by $S$. aureus, the increased level of methicillin-resistant and toxin producer Staphylococcus spp strains from food is to be considered. It is necessary that research be carried out in order to prevent the children health risks linked to the consumption of fermented dairy products. The aim of this study was to assess the toxinogenic and antibiotic susceptibility profiles of Staphylococci strains isolated from three types of fermented dairy products (yoghourt, couscous dêguê, and millet dêguê) sold in secondary schools in Cotonou and Abomey-Calavi in Benin.

\section{Materials and Methods}

2.1. Sampling and Sample Collection. In this study, 15 schools in Cotonou and Abomey-Calavi were selected using the "purposive" sampling technique for the sample collections [28]. Using this sampling method, 180 samples of the three selected fermented milk products (yoghourt, millet dêguê, and couscous dêguê) were collected from vendors located inside the schools or outside within a radius of 20 meters. The collected samples include 60 yoghourt samples, 60 millet dêguê samples, and 60 couscous dêguê samples. For each type of fermented dairy products, two samples were taken twice a day (morning and evening) and twice per week. Once collected, the samples were transported into an icebox (about $4^{\circ} \mathrm{C}$ ) to the laboratory for microbial analysis.

\subsection{Microbiological Analyses}

2.2.1. Isolation and Identification of Staphylococcus spp. Staphylococcus strains were isolated on Baird-Parker agar (OXOID CM0275) enriched with egg yolk and potassium tellurite [29]. Briefly, $10 \mathrm{~g}$ of each collected sample was homogenized into a sterile bottle, a stomacher with $90 \mathrm{ml}$ of sterile tryptone salt water. After incubation at $37^{\circ} \mathrm{C}$ for 24 hours, the isolated colonies were characterized by biochemical tests (catalase test, coagulase test, DNase test, and gallery API ${ }^{\circledR S T A P H)}[30]$.

2.2.2. Molecular Confirmation of Staphylococcus spp. The isolated Staphylococcus strains were confirmed molecularly through the PCR. The total DNA was manually extracted using the boiling method [31]. The PCR was performed in $30 \mu \mathrm{l}$ containing $15 \mu \mathrm{l}$ of $2 \mathrm{x}$ Master Mix (Biolabs), $1.5 \mu \mathrm{l}$ of forward primer (G1: 5'-GAAGTCGTAACAAGG-3'), $1.5 \mu \mathrm{l}$ of reverse primer (L1: $5^{\prime}$-CAAGGCATCCACCGT-3'), and $3 \mu \mathrm{l}$ of DNA. 25 cycles $\left(94^{\circ} \mathrm{C}\right.$ for 1 minute, $50^{\circ} \mathrm{C}$ for $30 \mathrm{~s}$, and of $72^{\circ} \mathrm{C}$ for $1 \mathrm{~min}$ ) was performed in a thermocycler (MultiGene, Labnet International, Inc.). The initial denaturation was done at $94^{\circ} \mathrm{C}$ for $5 \mathrm{~min}$, the final elongation was done at $72^{\circ} \mathrm{C}$ for $7 \mathrm{~min}$, and the amplified product was stored at $4^{\circ} \mathrm{C}$ until electrophoresis migration. The electrophoresis was performed at $150 \mathrm{~V}$ for $30 \mathrm{~min}$ on a $1.5 \%$ agarose gel containing ethidium bromide. A $100 \mathrm{bp}$ standard molecular ladder was used. The bands of 16 S-23 S gene of Staphylococcus spp were visualized at approximately $437 \mathrm{bp}$ [32] on the UV transillumination.

2.3. Phenotypic Detection of Toxins. The production of Panton and Valentine's leucocidin (luk-S/F), leukotoxin Luk-E/D, and the epidermolysins (ETA and ETB) was investigated on isolated strains by the radial immunoprecipitation method [33]. Briefly, fresh Staphylococcus colonies were cultured in $500 \mu \mathrm{l}$ of yeast casamino acid-pyruvate (YCP) broth at $37^{\circ} \mathrm{C}$ for $18-24 \mathrm{~h}$ with stirring (200 rpm). The supernatants of each sample of bacterial culture are collected after centrifugation $(5,000 \mathrm{rpm}$ for $5 \mathrm{~min})$. On a $0.6 \%$ agarose gel prepared with PBS, seven wells spaced $8 \mathrm{~mm}$ were dug. About $30 \mu \mathrm{l}$ of each supernatant was deposited in the corresponding external well. The appropriate purified rabbit antibodies $(\mathrm{OD}=3)$ are deposited in the central rosette well and control antigens $(\mathrm{OD}=0.2)$ in the top and bottom wells. The experiment was incubated at room temperature for 
TABLE 1: Staphylococcus spp bacterial load of the samples collected.

\begin{tabular}{lcc}
\hline Samples & $\begin{array}{c}\text { Staphylococcus spp } \\
(\mathrm{UFC} / \mathrm{ml})\end{array}$ & $\begin{array}{c}\text { Total coliforms } \\
(\mathrm{CFU} / \mathrm{ml})\end{array}$ \\
\hline Yoghourt & $754.3 * 10^{3}$ & $116.3 * 10^{3}$ \\
$\begin{array}{l}\text { Millet dêguê } \\
\text { Couscous }\end{array}$ & $1166.7 * 10^{3}$ & $1221.9 * 10^{3}$ \\
dêguê & $772.6 * 10^{3}$ & $769.7 * 10^{3}$ \\
\hline
\end{tabular}

about 16 hours. After incubation time, the precipitation arcs were observed directly or after staining with Coomassie blue [33].

2.4. Biofilm Training Research. From an $18 \mathrm{~h}$ culture in brain heart infusion, 48-well microplates (polystyrene) were inoculated with $10 \mu \mathrm{l}$ of dilute bacteria suspension to which $150 \mu \mathrm{l}$ of BCC was added. The microplates were incubated for $24 \mathrm{~h}$ at $37^{\circ} \mathrm{C}$. After incubation, the wells were washed three times with sterile physiological water (about $0.2 \mathrm{ml}$ ) to remove free bacteria (plankton). The biofilms formed by the adhesion of sessile organisms to the polystyrene support in each of the wells were stained with crystal violet $(0.1 \%)$ for $10 \mathrm{~min}$. The excess dye was thoroughly removed with sterile distilled water, and the plates were left at room temperature for drying. The results were compared to the positive and negative controls after incubation [34].

2.5. Antibiotics Susceptibility of Isolated Strains of Staphylococcus spp. The susceptibility of each Staphylococcus strain to antibiotics was determined by the diffusion method [35]. The tested antibiotics (Bio-Rad) were as follows: penicillin $\mathrm{G}(\mathrm{P}$ $10 \mu \mathrm{g}$ ), amikacin (AK $30 \mu \mathrm{g}$ ), fosfomycin (FOS $50 \mu \mathrm{g}$ ), cefoxitin (FOX $30 \mu \mathrm{g}$ ), gentamycin (GEN $10 \mu \mathrm{g}$ ), erythromycin (E $15 \mu \mathrm{g}$ ), lincomycin (MY $15 \mu \mathrm{g}$ ), ciprofloxacin (CF $5 \mu \mathrm{g}$ ), ofloxacin (OFX $5 \mu \mathrm{g}$ ), amoxicillin (AMO $20 \mu \mathrm{g}$ ), cefotaxime (CTX $30 \mu \mathrm{g}$ ), tetracycline (TET $30 \mu \mathrm{g}$ ), trimethoprim-sulfamethoxazole (SXT 23.75 $\mu \mathrm{g}$ ), amoxicillin-clavulanic acid (AMC $20 \mu \mathrm{g}$ ), and fusidic acid (FD $10 \mu \mathrm{g}$ ).

2.6. Data Analysis. Microsoft Office Excel 2010 spreadsheet was used for data processing. The statistical analysis and graphs were made using the $\mathrm{R}$ 3.6.1. The test is considered statistically significant if $p<0.05$.

\section{Results}

\subsection{Microbiological Quality of the Collected Fermented Dairy Products}

3.1.1. Enumeration of Staphylococcus spp Germs in the Fermented Dairy Products Analyzed. The results of germ enumeration in fermented dairy products collected, expressed in CFU/ml, are presented in Table 1. They represent the microbial load of the various microorganisms sought in the yoghourt, the millet dêgue, and the couscous dêgue analyzed. The analysis of this table shows that the microbial loads vary according to sample types. The most contaminated samples were those of millet dêguê and the least contaminated were those of yoghourt $\left(754.3 * 10^{3}\right.$ $\mathrm{CFU} / \mathrm{ml})$. Regarding total coliforms, millet dêguê samples were the most contaminated $\left(1166.7 * 10^{3} \mathrm{CFU} / \mathrm{ml}\right)$ and the least contaminated were the yoghourt samples.

3.1.2. Staphylococcus Species Found in the Fermented Dairy Products Analyzed. Staphylococcus spp strains were isolated at $42.77 \%$ from the 180 collected samples. The $16 \mathrm{~S}-23 \mathrm{~S}$ gene from Staphylococcus spp was present in all of our isolated strains. A total of 13 species of Staphylococcus were identified. S. aureus was the only coagulase-positive species identified in our samples. The three most represented species were S. aureus (36.36\%), S. xylosus (19.48\%), and S. capitis (18.18\%). S. auricularis, S. cohnii spp cohnii, S. cohnii spp urealyticus, and $S$. warneri were the least isolated with a respective rate of $1.3 \%$ (Figure 1 ).

3.1.3. Distribution of Staphylococcus spp Strains Isolated according to the Fermented Dairy Products. Figure 2 shows the distribution of the 13 identified Staphylococcus strains according to the kind of fermented milk products. The distribution of species according to the different types of fermented milk products is not statistically significant $(p>0.05)$. However, it appears that $S$. aureus was the most isolated irrespective of the milk products. Ten different species were identified in the couscous dêguê, seven species in yoghourt, and six species in the millet dêguê. S. aureus, S. xylosus, and S. capitis were present in three kinds of products.

3.1.4. Distribution of Staphylococcus spp Strains Isolated according to the Time of Collection. Figure 3 shows that couscous dêguê samples were more contaminated in the morning (16.29\%) than in the afternoon (14.29\%). The yoghourt samples were more contaminated in the afternoon $(23.38 \%)$ than in the morning $(18.18 \%)$.

3.2. Distribution of Biofilm Formation according to the Isolated Staphylococcus Species. Biofilm production does not vary statistically according to the Staphylococcus species $(p>0.05)$. The biofilm production capacity of isolated Staphylococcus shows that $S$. aureus was the most biofilm $(27.6 \%)$ formative followed by $S$. capitis $(24.1 \%)$ and S. xylosus (20.7\%) (Figure 4). None of S. cohnii spp cohnii, $S$. cohnii ssp urealyticus, and S. schleiferi produced biofilm.

The Staphylococcus strains isolated from yoghourt (48.28\%) made more biofilm while those isolated from couscous dêguê (17.24\%) made less (Figure 5). Biofilm production by the different isolated species in the function of sample types is statistically significant $(p=0.042)$.

3.3. Distribution of Toxin Production by Isolated Staphylococcus spp Strains. The isolated Staphylococcus spp were predominantly producing epidermolysin B (ETB) at a rate of $37.5 \%$ for coagulase-negative Staphylococcus strains and 25\% for coagulase-positive Staphylococcus. Luk-S/F was 


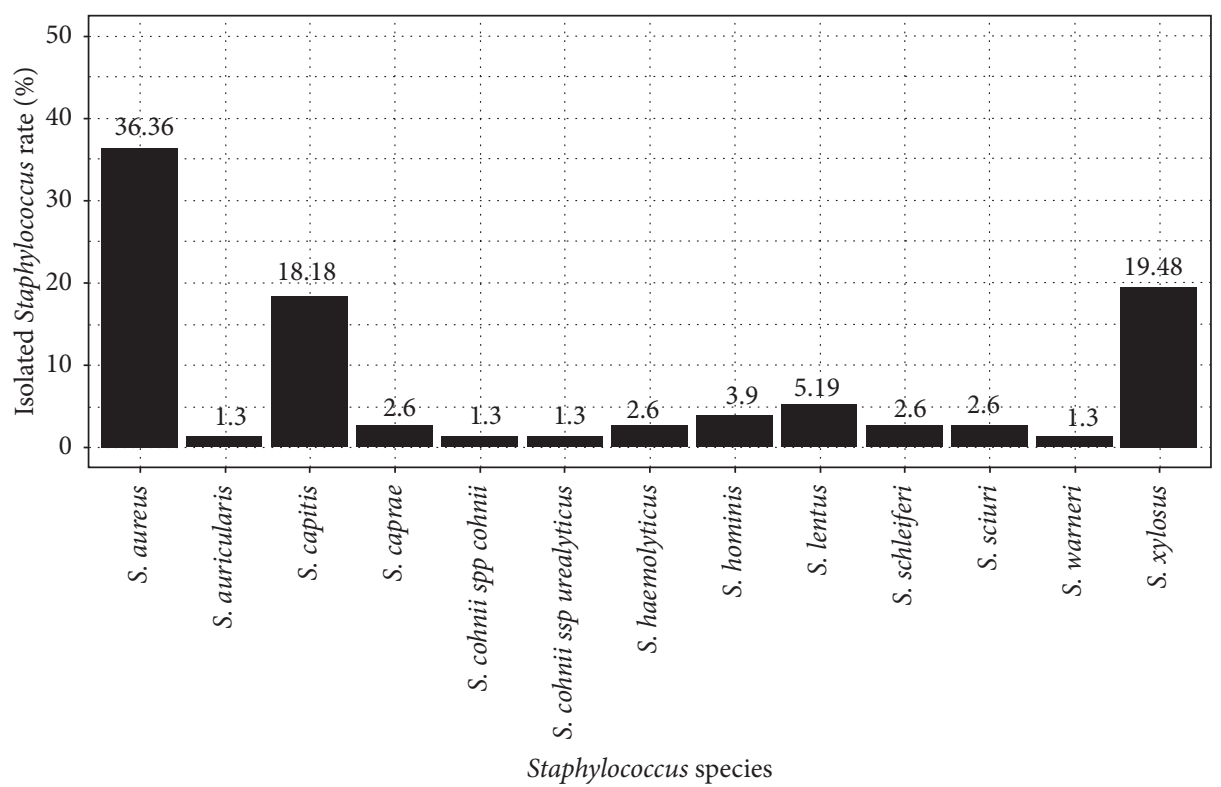

Figure 1: Rate of the different species of Staphylococcus found.

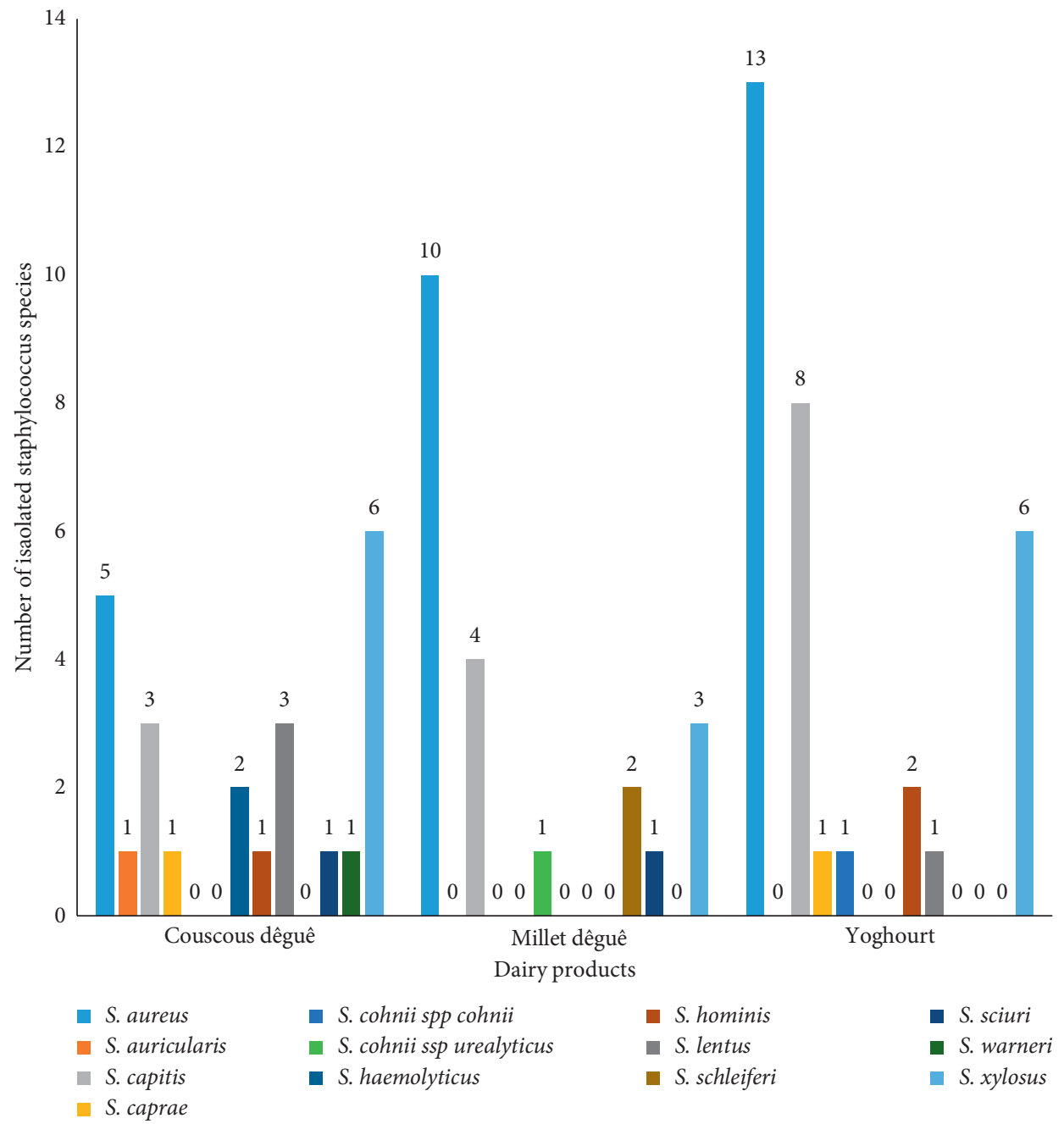

FIGURE 2: Distribution of Staphylococcus spp strains according to fermented milk products. 


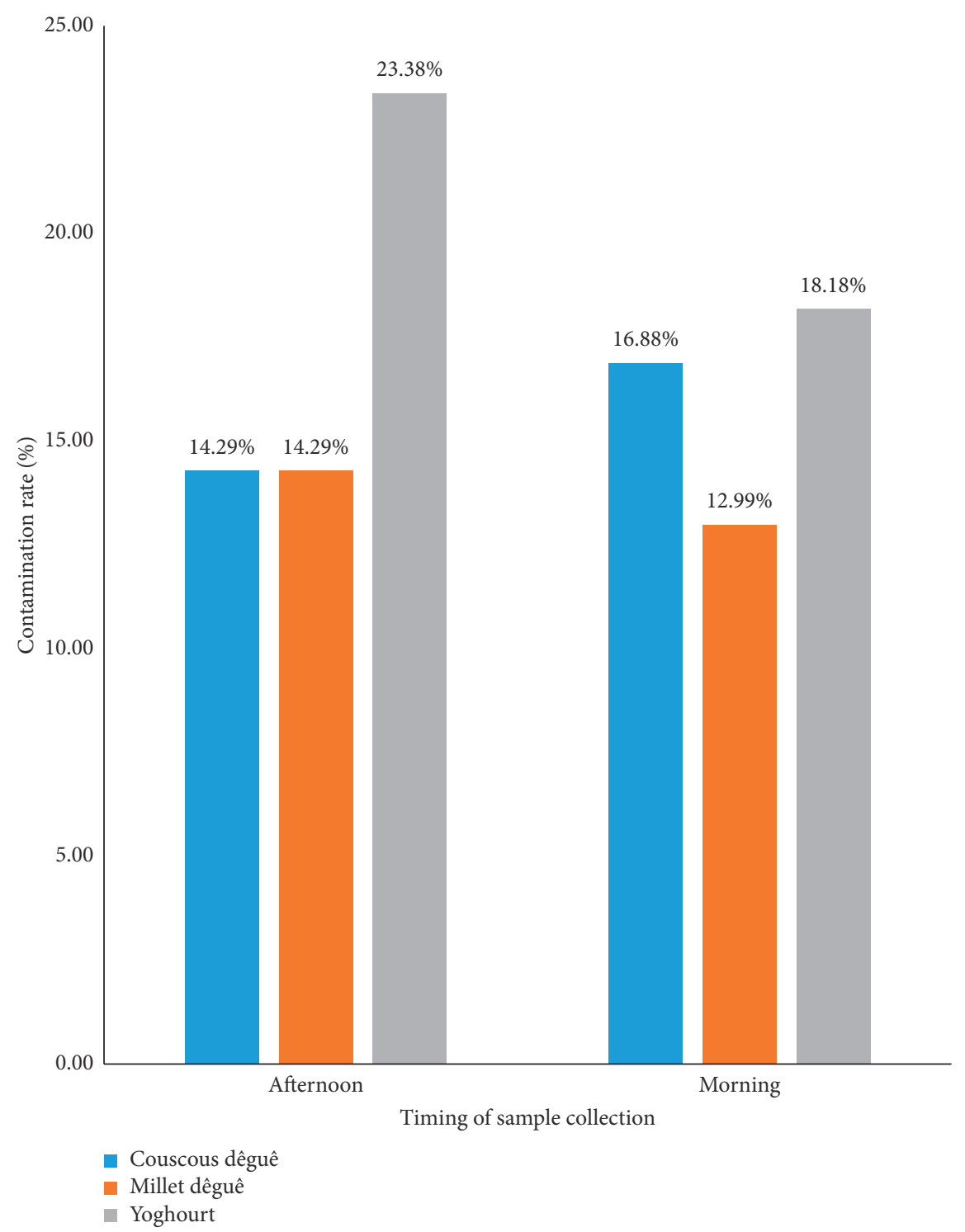

Figure 3: Distribution of Staphylococcus spp strains according to the time of collection.

produced by only S. aureus strains at a rate of $8.33 \%$. Only coagulase-negative Staphylococcus have produced Luk-E/D (Figure 6).

In the samples collected in the morning, only ETA and ETB toxins were produced by the Staphylococcus strains. ETB-producer strains were present in the afternoon samples. Luk-E/D and Luk-S/F toxins were produced only by Staphylococcus strains isolated in the afternoon (Figure 7).

3.4. Susceptibility of Isolated Staphylococcus spp Strains to Antibiotics. All the Staphylococcus strains were resistant to penicillin, and $93.51 \%$ were resistant to lincomycin. About $70.13 \%$ were resistant to cefoxitin, and $60 \%$ were resistant to the antibiotics of the $\beta$-lactam family. The lowest resistance rate was observed with ciprofloxacin (22.08\%) (Figure 8).

For coagulase-negative Staphylococcus (CNS), the resistance of 6 antibiotics (ciprofloxacin, erythromycin, ofloxacin, trimethoprim-sulfamide, and tetracycline) was less to $50 \%$. The lowest resistance was observed on S. aureus with ciprofloxacin (28.6\%), followed by erythromycin (39.3\%). The resistance of S. aureus to methicillin (cefoxitin) was $71.4 \%$ (Figure 9).

\section{Discussion}

The evaluation of the microbiological quality of fermented milk (yoghourt, millet dêguê, and couscous dêguê) products reveals the presence of total coliforms and Staphylococcus germs. This observation is consistent with the work of Kukhtyn et al. [36], who find that the greatest danger in the process of making milk and milk products is the contamination of pathogens. Dairy products are highly moisture and offer suitable growth conditions for many pathogens including $S$. aureus that has frequently been the cause of foodborne diseases [37]. It is thus important to implement 




FIgURE 4: Biofilm production rate by isolated Staphylococcus species.

microbiological regulations for each dairy product to reduce food poisoning by fermented dairy products. The presence of $S$. aureus illustrates a failure in hygiene and in the implementation of good manufacturing practice. The search for these germs at the industrial level constitutes a test of overall hygienic quality. The microbiological quality of dairy products is important in the prevention of food poisoning. Thus, in this study, we observed a very high presence of total coliforms and Staphylococci. It emerged from our investigations that $36.36 \%$ of the strains of Staphylococci isolated were coagulase-positive (Staphylococcus aureus) and 63.64\% were coagulase-negative (Figure 1). The presence of S. aureus in dairy products could alter the microbiological quality of these products and cause food poisoning [38]. Worldwide, $S$. aureus has been isolated from several ready-to-eat products. The presence of those microorganisms indicates potentially cross-contamination that may be due to improper staff hygiene and/or poor surface sanitation. Indeed, $S$. aureus strains were isolated from food handlers, foods, and patient specimens [39]. This microorganism is capable of surviving on dry stainless steel, and it can easily be transferred from sponges to stainless steel surfaces and subsequently to food products [40]. In milk transformation, $S$. aureus can contaminate the production at almost every step. Therefore, S. aureus can be shed directly into the milk and produce enterotoxins that represents one of the most common food safety concerns from raw milk products [41-43].

As in our study, some authors observed in the United States [44], Egypt [45], and Morocco [46] diversity in the presence of coagulase-negative Staphylococcus strains. The ones commonly detected in raw milk are S. epidermidis, S. simulans, S. hominis, S. caprae, S. warneri, and S. xylosus $[44,47,48]$. In our study, the most dominant coagulasenegative strain was $S$. xylosus. But Organji et al. [48] observed in their study on milk in Egypt that S. saprophyticus was the most dominant coagulase-negative strain. This difference in proportion can be explained by the fact that our samples were not fermented enough because S. saprophyticus plays a role in the fermentation process [49]. In this respect, probably no health risks are associated with all Staphylococci detected in fermented dairy products samples. Considering the collection period, the yogurt samples are most contaminated by Staphylococci in the 


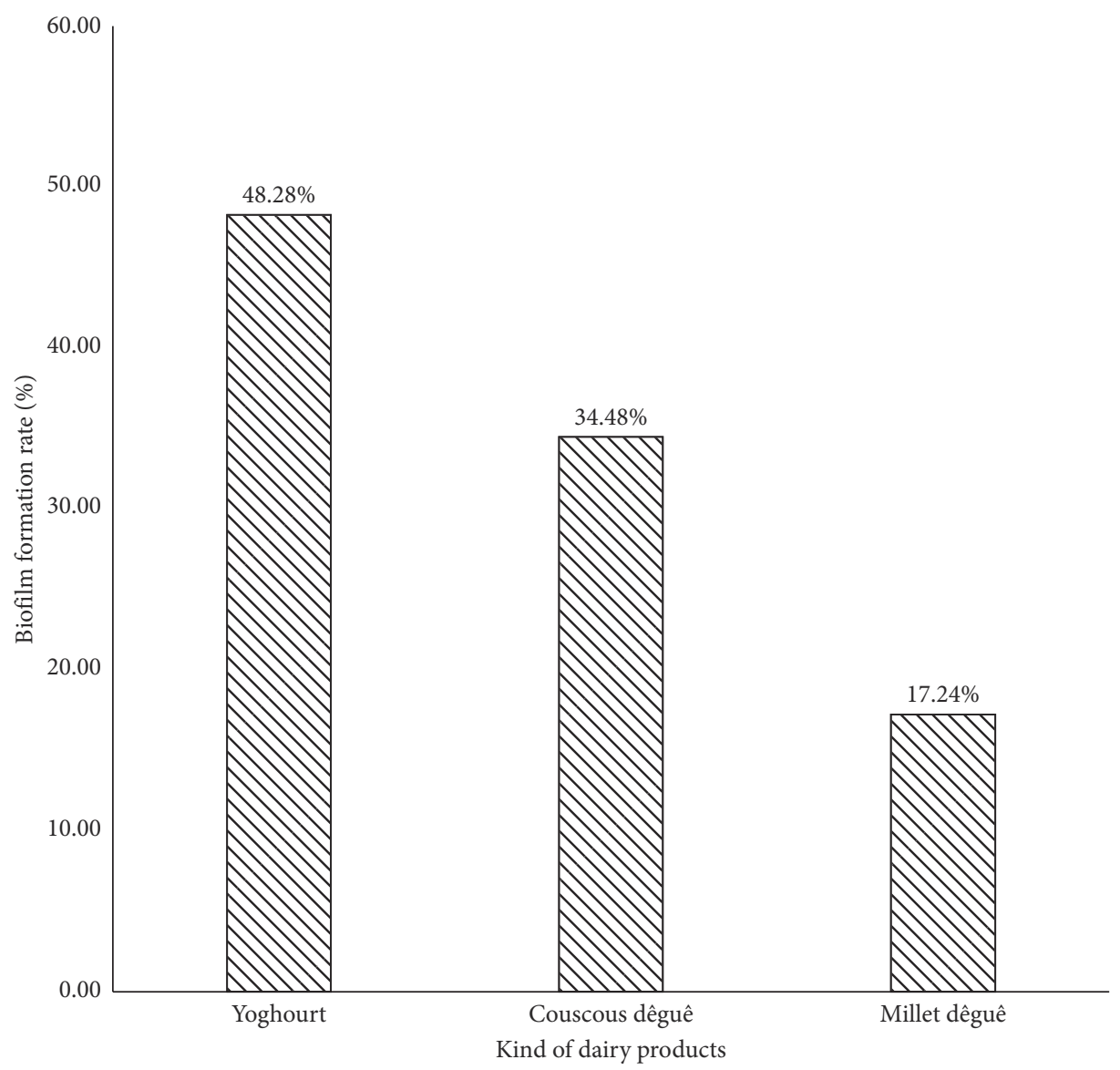

Figure 5: Biofilm production rate according to Staphylococcus spp strains in the different samples.

afternoon $(23.38 \%)$ than in the morning (18.18\%). This result is lower than the results found by Tondo et al. [50] who found $90.4 \%$ contamination of $S$. aureus in raw milk taken in the morning. This difference could be explained by the fermentation and pasteurization processes that yogurt undergoes.

Concerning the formation of biofilm capability, S. aureus displays the highest rate (27.6\%). In addition, the yogurt samples were those that contained more strains $(48.28 \%)$ of biofilm-forming Staphylococci. Indeed, S. aureus can produce a multilayer biofilm incorporated into a glycocalyx with the expression of heterogeneous proteins overall, forming at least two types of biofilms: ica-dependent and ica-independent [51]. The formation of biofilm by foodborne staphylococcal strains (especially yogurt) is very serious for human prognosis, especially for children who are the biggest consumers of it. This biofilm formation is more observed in clinical strains [52]. Biofilm formation in dairy equipment as well as insufficient acidification during fermentation opens $S$. aureus niches for multiplication and efficient contamination of the dairy processing lines [17].

The pathogenicity of Staphylococcus strains is attributable to toxin production and their antibiotic-resistant profile [53]. Toxin research revealed that Panton and Valentine's leucocidin was produced ( $8.33 \%)$ only by $S$. aureus. The most produced toxin is epidermolysin B (62.5\%) by all strains of Staphylococcus. This result is higher than the 27.59\% founded by Ahouandjinou et al. [54] among the Staphylococci strains isolated from bovine carcasses in Benin. The PVL production obtained in our study is lower than the $15 \%$ obtained in Benin by Baba-Moussa et al. [55] for direct debits of all origins. Baba-Moussa et al. [56] showed that $21.50 \%$ of the S. aureus strains isolated from CHU infections produced PVL. This toxin, in clinical practice, is associated with skin diseases such as boils and abscesses [57]. Thus, the production of PVL by food strains must also challenge us especially in terms of its virulence. This presence may be due to the carrying of these types of ailments by sellers that would facilitate the transmission from humans to food. $S$. aureus is able to survive on dry stainless steel and it can easily be transferred from any surfaces to food products [40]. Therefore, in the milk transformation process, $S$. aureus can contaminate the production at almost every step. S. aureus can be shed directly into the milk and produce exotoxins that represents one of the most common food safety concerns from raw milk products $[41-43,58]$. In addition, toxins can be produced in the product during storage of the fermented dairy product if conditions allow the growth of $S$. aureus.

The study of the sensitivity to antibiotics of isolated Staphylococcus strains showed the existence of resistance, 


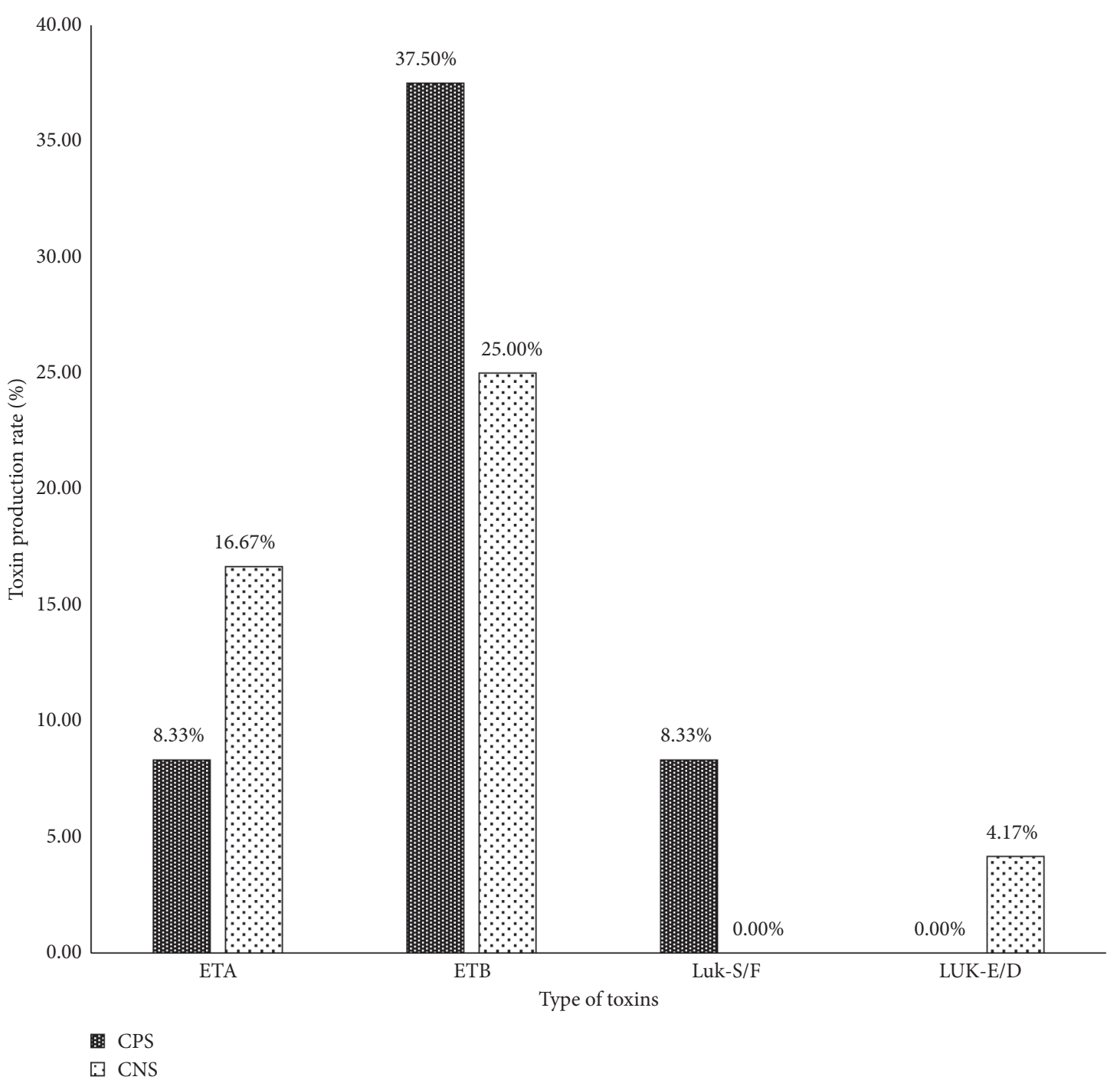

FIgURE 6: Rate of toxin production by Staphylococcus spp strains.

with variable proportions according to the families of antibiotics. In fact, the Staphylococcus spp show a high resistance rate to penicillin (100\%), lincomycin $(93.51 \%)$, and cefotaxime (90.91\%). These results are consistent with those reported on staphylococcal strains isolated from street foods in Benin [10] and Ethiopia [59]. This high resistance level to antibiotics observed can be due to self-medication and excessive and uncontrolled use of antibiotics. The lowest resistance of $S$. aureus observed was with ciprofloxacin (28.6\%). This result is close to the $31.3 \%$ obtained in studies carried out on milk by Wang et al. [60]. About $71 \%$ of the $S$. aureus were resistant to methicillin (cefoxitin). These results are higher than the $15.18 \%$ found by Sina et al. [10]. The coagulase-negative staphylococcal strains displayed methicillin resistance rates of $69.4 \%$. Our results concerning this antibiotic are slightly lower than those reported for clinical strains in Turkey on coagulase-negative Staphylococci [61]. This difference may be caused by the fact that clinical strains are more in contact with the antimicrobial molecule than food strains. The Staphylococcus spp. methicillin resistance observed in this study suggests that it involves the resistance of most of the $\beta$-lactams currently available [62]. However, the proportion is frightening for food since it is reported that methicillin-resistant Staphylococcus strains began to develop resistance to many antibiotics (quinolones, macrolides, aminoglycosides, tetracyclines, trimethoprim-sulfamethoxazole, clindamycin, and chloramphenicol) widely used to control staphylococcal infection $[63,64]$, such as food poisoning. The sellers who do not protect their hands and head and do not observe hygiene rules during the manufacturing of dairy products quickly find themselves contaminated by potentially pathogenic Staphylococcus strains that are antibiotics-resistant, 


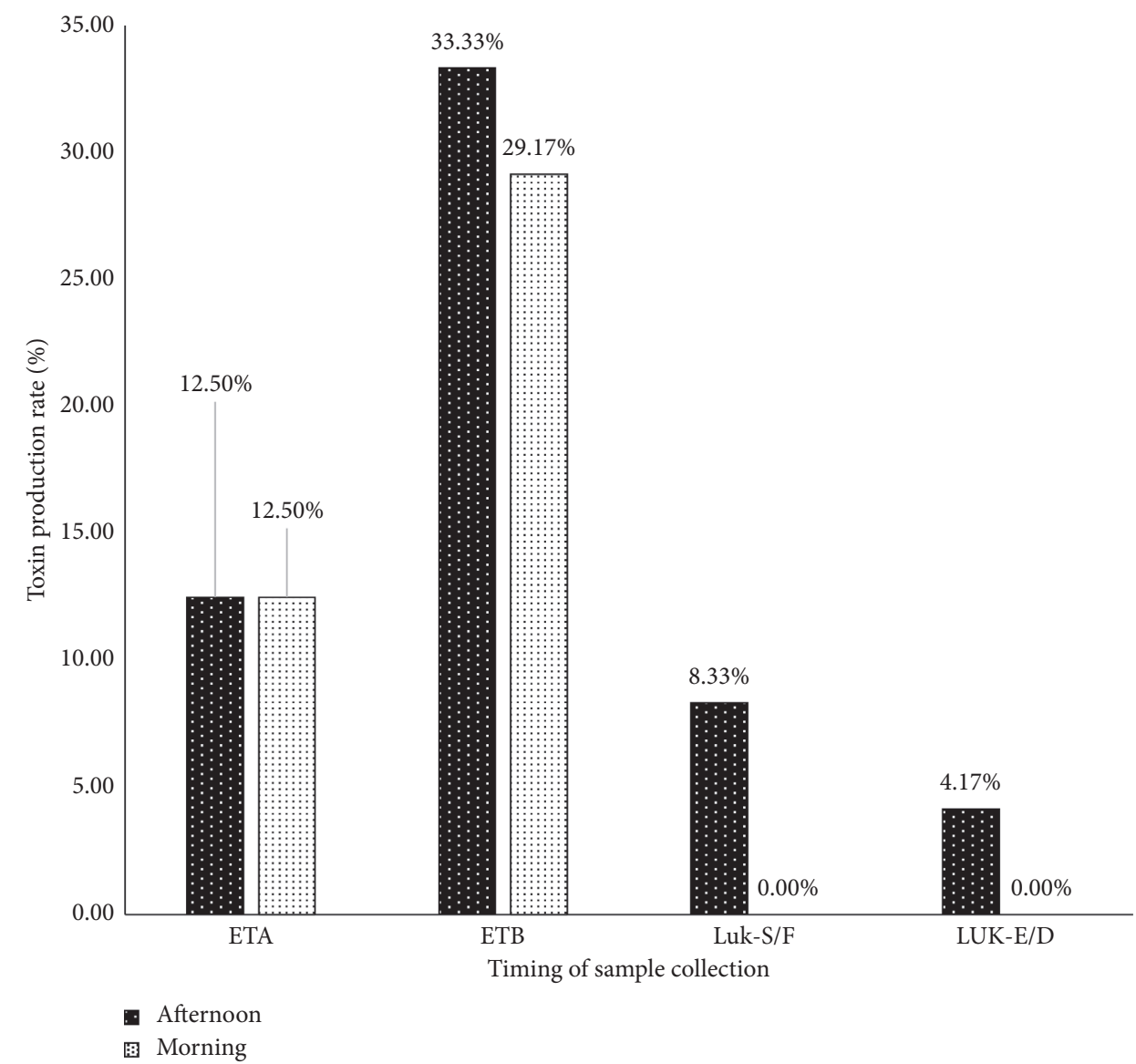

Figure 7: Rate of toxin production by Staphylococcus spp according to the timing of sample collection.

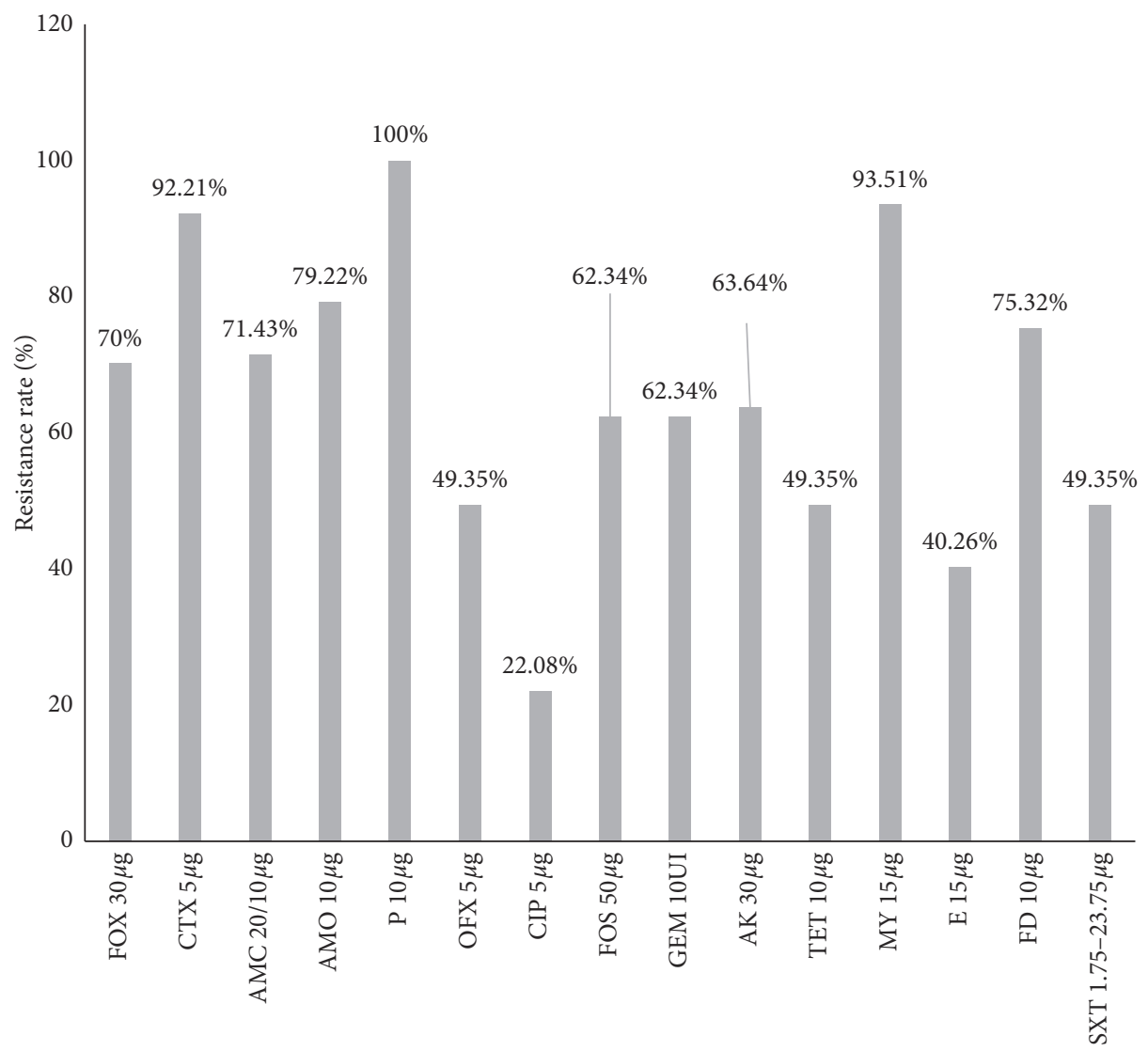

Tested antibiotics

FIgURE 8: Resistance rate of isolated Staphylococci strains to antibiotics. 


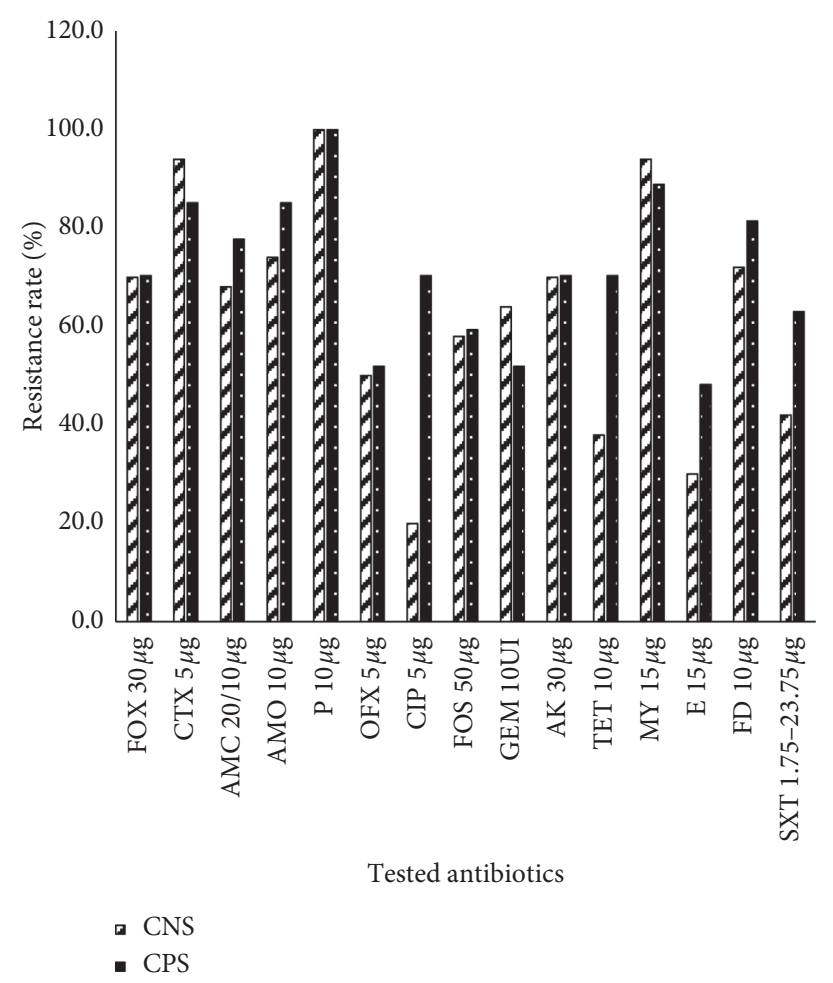

FIgUre 9: Antibiotic resistance rate of strains of negative coagulase Staphylococcus spp (NCS) and S. aureus (CPS) isolated.

producing toxins, and forming biofilms. This situation is a real problem for food safety.

\section{Conclusion}

Staphylococcal food poisoning is of major concern in public health programs worldwide. Results clearly indicated that the fermented milk products analyzed were contaminated with 13 species of Staphylococcus, namely, S. aureus. Human, animal, and environmental sources could be incriminated in the contamination of dairy products. Resistant and toxinproducing strains were also isolated from the collected fermented milk products. There is a high risk of food poisoning associated with the consumption of those dairy products. We can say that good hygienic and manufacturing practices along each step of the selected dairy fermented production chain are of great importance and necessary to eliminate the dissemination of potentially pathogenic Staphylococci in the community. Thus, more measures focusing on hygienic prevention are required to reduce contamination by Staphylococci.

\section{Data Availability}

The data are available from the corresponding author upon request.

\section{Conflicts of Interest}

The authors declare there are no conflicts of interest in the publication of this manuscript.

\section{Acknowledgments}

This work was supported by the International Foundation of Science (IFS), Grant no. I-3-E-5393-2.

\section{References}

[1] K. Rafferty and R. P. Heaney, "Nutrient effects on the calcium economy: emphasizing the potassium controversy," The Journal of Nutrition, vol. 138, no. 1, pp. 166S-171S, 2008.

[2] E. H. Soundous, G. Amaury, D. L. Juliette, D. T. Sybille, L. Aurélie, and S. Marianne, "Overview of the local production process of raw milk butter in Wallonia (Belgium)," International Journal of Dairy Technology, vol. 72, no. 3, pp. 466-471, 2019.

[3] J. M. Ruvalcaba Gómez, H. Ruiz Espinosa, R. I. Arteaga Garibay et al., "Texture, physicochemical and sensory properties of artisanal adobera cheese from Los Altos de Jalisco, a genuine Mexican cheese," International Journal of Dairy Technology, vol. 73, no. 2, pp. 411-420, 2020.

[4] A. C. Ross, S. A. Abrams, J. F. Aloia et al., Committee to Review Dietary Reference Intakes for Vitamin D and Calcium Food and Nutrition Board, Institute of Medicine Dietary Reference Intakes for Calcium and Vitamin D, National Academies Press, Washington, DC, 2001.

[5] A. Tankoano, D. Kabore, A. Savadogo et al., "Evaluation of microbiological quality of raw milk, sour milk and artisanal yoghurt from Ouagadougou, Burkina Faso," African Journal of Microbiology Research, vol. 10, no. 16, pp. 535-541, 2016.

[6] D. Malvy, F. Djossou, and M. Le Bras, Intoxications Aux Urgences, P. Zetlaoui and M. Lenoble, Eds., pp. 127-148, Elsevier, Amsterdam, Netherlands, 2004.

[7] M. G. Tohoyessou, W. Mousse, H. Sina et al., "Microbial quality of artisanal yoghurt and Dèguè products collected in 
schools of Cotonou and Abomey-Calavi (Benin)," African Journal of Food Science, vol. 14, no. 5, pp. 112-118, 2020.

[8] J. D. Oliver, "The viable but nonculturable state in bacteria," The Journal of Microbiology, vol. 43, no. 1, pp. 93-100, 2005.

[9] L. C. Garas, C. A. Cooper, M. W. Dawson, J. L. Wang, J. D. Murray, and E. A. Maga, "Young pigs consuming lysozyme transgenic goat milk are protected from clinical symptoms of enterotoxigenic Escherichia coli infection," The Journal of Nutrition, vol. 147, no. 11, pp. 2050-2059, 2017.

[10] H. Sina, F. Baba-Moussa, A. P. Kayodé et al., "Characterization of Staphylococcus aureus isolated from street foods: toxin profile and prevalence of antibiotic resistance," Journal of Applied Biosciences, vol. 46, pp. 3133-3143, 2011.

[11] T. Li, G. Wang, P. Yin et al., "Effect of negative pressure on growth, secretion and biofilm formation of Staphylococcus aureus," Antonie Van Leeuwenhoek, vol. 108, no. 4, pp. 907-917, 2015.

[12] M. Damm, C. Holm, M. Blaabjerg, M. N. Bro, and D. Schwarz, "Differential somatic cell count-a novel method for routine mastitis screening in the frame of dairy herd improvement testing programs," Journal of Dairy Science, vol. 100, no. 6, pp. 4926-4940, 2017.

[13] S. Zare, A. Derakhshandeh, M. Haghkhah, Z. Naziri, and A. M. Broujeni, "Molecular typing of Staphylococcus aureus from different sources by RAPD-PCR analysis," Heliyon, vol. 5, no. 8, p. e02231, 2019.

[14] Z. F. Haque, A. A. M. Sabuj, M. M. Mahmud, A. Pondit, M. A. Islam, and S. Saha, "Characterization of Staphylococcus aureus from milk and dairy products sold in some local markets of Mymensingh district of Bangladesh," Journal of Nutrition and Food Sciences, vol. 8, no. 6, p. 743, 2018.

[15] A. O. Adejuwon, E. O. Agbaje, and N. Idika, "Antifungal and antibacterial activities of aqueous and methanolic root extracts of Carica papaya linn. (Caricaceae)," International Research Journal of Microbiology, vol. 2, no. 8, pp. 270-277, 2011.

[16] R. T. Gergova, V. S. Tsitou, I. I. Gergova, A. A. Muhtarova, and I. G. Mitov, "Correlation of methicillin resistance and virulence genes of Staphylococcus aureus with infection types and mode of acquisition in Sofia, Bulgaria," African Journal of Clinical and Experimental Microbiology, vol. 20, no. 4, pp. 280-288, 2019.

[17] M. Sharma and S. K. Anand, "Biofilms evaluation as an essential component of HACCP for food/dairy processing industry-a case," Food Control, vol. 13, no. 6-7, pp. 469-477, 2002.

[18] D. Gutiérrez, S. Delgado, D. Vázquez-Sánchez et al., "Incidence of Staphylococcus aureus and analysis of associated bacterial communities on food industry surfaces," Applied and Environmental Microbiology, vol. 78, no. 24, pp. 8547-8554, 2012.

[19] S. Chairat, H. Gharsa, C. Lozano et al., "Characterization of Staphylococcus aureus from raw meat samples in Tunisia: detection of clonal lineage ST398 from the African continent," Foodborne Pathogens and Disease, vol. 12, no. 8, pp. 686-692, 2015.

[20] M. Ben Said, M. S. Abbassi, V. Bianchini et al., "Genetic characterization and antimicrobial resistance of Staphylococcus aureusisolated from bovine milk in Tunisia," Letters in Applied Microbiology, vol. 63, no. 6, pp. 473-481, 2016.

[21] M. A. Al-Ashmawy, K. I. Sallam, S. M. Abd-Elghany, M. Elhadidy, and T. Tamura, "Prevalence, molecular characterization, and antimicrobial susceptibility of methicillin-resistant Staphylococcus aureus isolated from milk and dairy products," Foodborne Pathogens and Disease, vol. 13, no. 3, pp. 156-162, 2016.

[22] G. N. Viçosa, C. Botta, I. Ferrocino et al., "Staphylococcus aureus undergoes major transcriptional reorganization during growth with Enterococcus faecalis in milk," Food Microbiology, vol. 73, pp. 17-28, 2018.

[23] G. Normanno, G. La Salandra, A. Dambrosio et al., "Occurrence, characterization and antimicrobial resistance of enterotoxigenic Staphylococcus aureus isolated from meat and dairy products," International Journal of Food Microbiology, vol. 115, no. 3, pp. 290-296, 2007.

[24] D. Sergelidis and A. S. Angelidis, "Methicillin-resistant Staphylococcus aureus: a controversial food-borne pathogen," Letters in Applied Microbiology, vol. 64, no. 6, pp. 409-418, 2017.

[25] I. V. Pinchuk, E. J. Beswick, and V. E. Reyes, "Staphylococcal enterotoxins," Toxins, vol. 2, no. 8, pp. 2177-2197, 2010.

[26] D.-L. Hu and A. Nakane, "Mechanisms of staphylococcal enterotoxin-induced emesis," European Journal of Pharmacology, vol. 722, pp. 95-107, 2014.

[27] T. A. Ahoyo, H. Ahissou, F. Kounon, T. Aminou, and K. Dramane, "Etude de la qualité bactériologique des aliments vendus sur le campus de l'Université d'Abomey-Calavi au Bénin," International Journal of Biological and Chemical Sciences, vol. 4, no. 4, pp. 1083-1092, 2010.

[28] I. Etikan, S. A. Musa, and R. S. Alkassim, "Comparison of convenience sampling and purposive sampling," American Journal of Theoretical and Applied Statistics, vol. 5, no. 1, pp. 1-4, 2016.

[29] A. C. Baird-Parker, "Foodborne salmonellosis," The Lancet, vol. 336, no. 8725, pp. 1231-1235, 1990.

[30] P. Riegel, M. Archambaud, D. Clavé, and M. Vergnaud, Bacteria Difficult to Culture and Identify, pp. 93-112, Biomerous, France, 2006.

[31] R. S. Rasmussen and M. T. Morrissey, "DNA-based methods for the identification of commercial fish and seafood species," Comprehensive Reviews in Food Science and Food Safety, vol. 7, no. 3, pp. 280-295, 2008.

[32] M. Mendoza, H. Meugnier, M. Bes, J. Etienne, and J. Freney, "Identification of Staphylococcus species by 16S-23S rDNA intergenic spacer PCR analysis," International Journal of Systematic Bacteriology, vol. 48, no. 3, pp. 1049-1055, 1998.

[33] A. Gravet, D. A. Colin, D. Keller, R. Girardot, H. Monteil, and G. Prévost, "Characterization of a novel structural member, LukE-LukD, of the bi-component staphylococcal leucotoxins family," FEBS Letters, vol. 436, no. 2, pp. 202-208, 1998.

[34] S. Stepanović, D. Vuković, I. Dakić, B. Savić, and M. ŠvabićVlahović, "A modified microtiter-plate test for quantification of staphylococcal biofilm formation," Journal of Microbiological Methods, vol. 40, no. 2, pp. 175-179, 2000.

[35] CA-SFM and EUCAST, 2019, https://www.sfm-microbiologie. org/2019/05/06/casfm-eucast-2019-v2/.

[36] M. D. Kukhtyn, Y. V. Horyuk, V. V. Horyuk, T. Y. Yaroshenko, O. I. Vichko, and O. S. Pokotylo, "Biotype characterization of Staphylococcus aureus from milk and dairy products of private production in the western regions of Ukraine," Regulatory Mechanisms in Biosystems, vol. 8, no. 3, pp. 384-388, 2017.

[37] J. F. Veras, L. S. do Carmo, L. C. Tong, et al., A study of the entero toxigenicity of coagulase-negative and coagulase-positive staphylococcal isolates from food poisoning outbreaks in Minas Gerais, Brazil," International Journal of Infectious Diseases, vol. 12, no. 4, pp. 410-415, 2008. 
[38] C. Lapeyre, "Détection des entérotoxines staphylococciques: enrichir l'extrait," Revue Laitière Française, vol. 577, pp. 36-37, 1997.

[39] J. Kümmel, B. Stessl, M. Gonano et al., "Staphylococcus aureus entrance into the dairy chain: tracking S. aureus from dairy cow to cheese," Frontiers in Microbiology, vol. 7, p. 1603, 2016.

[40] H. Kusumaningrum, G. Riboldi, W. C. Hazeleger, and R. R. Beumer, "Survival of foodborne pathogens on stainless steel surfaces and cross-contamination to foods," International Journal of Food Microbiology, vol. 85, no. 3, pp. 227236, 2003.

[41] A. Kérouanton, J. A. Hennekinne, C. Letertre et al., "Characterization of Staphylococcus aureus strains associated with food poisoning outbreaks in France," International Journal of Food Microbiology, vol. 115, no. 3, pp. 369-375, 2007.

[42] H. Fagundes, L. Barchesi, A. Nader Filho, L. M. Ferreira, and C. A. F. Oliveira, "Occurrence of Staphylococcus aureus in raw milk produced in dairy farms in São Paulo state, Brazil," Brazilian Journal of Microbiology, vol. 41, no. 2, pp. 376-380, 2010.

[43] V. M. Silveira-Filho, I. S. Luz, A. P. F. Campos et al., "Antibiotic resistance and molecular analysis of Staphylococcus aureus isolated from cow's milk and dairy products in northeast Brazil," Journal of Food Protection, vol. 77, no. 4, pp. 583-591, 2014.

[44] A. A. Sawant, B. E. Gillespie, and S. P. Oliver, "Antimicrobial susceptibility of coagulase-negative Staphylococcus species isolated from bovine milk," Veterinary Microbiology, vol. 134, no. 1-2, pp. 73-81, 2009.

[45] K. M. Osman, K. A. Abd El-Razik, H. S. H. Marie, and A. Arafa, "Coagulase-negative Staphylococci collected from bovine milk: species and antimicrobial gene diversity," Journal of Food Safety, vol. 36, no. 1, pp. 89-99, 2015.

[46] A. Bendahou, M. Abid, N. Bouteldoun, D. Catelejine, and M. Lebbadi, "Enterotoxigenic coagulase positive Staphylococcus in milk and milk products, lben and jben, in Northern Morocco," The Journal of Infection in Developing Countries, vol. 3, no. 03, pp. 169-176, 2009.

[47] A. Bendahou, M. Lebbadi, L. Ennanei, F. Z. Essadqui, and M. Abid, "Characterization of Staphylococcus species isolated from raw milk and milk products (lben and jben) in North Morocco," The Journal of Infection in Developing Countries, vol. 2, no. 3, pp. 218-225, 2008.

[48] S. R. Organji, H. H. Abulreesh, K. Elbanna, G. E. H. Osman, and M. H. K. Almalki, "Diversity and characterization of Staphylococcus spp. in food and dairy products: a foodstuff safety assessment," Journal of Microbiology, Biotechnology and Food Sciences, vol. 7, no. 6, p. 586, 2018.

[49] B. Geniş and Y. Tuncer, "Determination of antibiotic susceptibility and decarboxylase activity of coagulase-negative Staphylococcus and Macrococcus caseolyticus strains isolated from fermented Turkish sausage (sucuk)," Journal of Food Processing and Preservation, vol. 42, no. 1, p. e13329, 2018.

[50] E. C. Tondo, M. M. Guimarães, J. A. Henriques, and M. A. Ayub, "Assessing and analysing contamination of a dairy products processing plant by Staphylococcus aureus using antibiotic resistance and PFGE," Canadian Journal of Microbiology, vol. 46, no. 12, pp. 1108-1114, 2000.

[51] C. Beloin and J.-M. Ghigo, "Finding gene-expression patterns in bacterial biofilms," Trends in Microbiology, vol. 13, no. 1, pp. 16-19, 2005.

[52] M. A. Jabra-Rizk, T. F. Meiller, C. E. James, and M. E. Shirtliff, "Effect of farnesol on Staphylococcus aureus biofilm formation and antimicrobial susceptibility," Antimicrobial Agents and Chemotherapy, vol. 50, no. 4, pp. 1463-1469, 2006.

[53] H. M. Yehia, E. A. Ismail, Z. K. Hassan, A. H. Al-Masoud, and M. M. Al-Dagal, "Heat resistance and presence of genes encoding staphylococcal enterotoxins evaluated by multiplexPCR of Staphylococcus aureus isolated from pasteurized camel milk," Bioscience Reports, vol. 3911 pages, 2019.

[54] H. Ahouandjinou, F. Baba-Moussa, H. Sina et al., "Variability and antibiotics resistance of Staphylococcus sp flora among the cattle carcasses," International Journal of Science, Environment and Technology, vol. 5, no. 5, pp. 3275-3288, 2016.

[55] L. B. Moussa, A. Sanni, A. Y. Dagnra et al., "Approche épidémiologique de l'antibiorésistance et de la production de leucotoxines par les souches de Staphylococcus aureus isolées en Afrique de l'Ouest," Médecine et Maladies Infectieuses, vol. 29, no. 11, pp. 689-696, 1999.

[56] L. Baba-Moussa, L. Anani, J. M. Scheftel et al., "Virulence factors produced by strains of Staphylococcus aureus isolated from urinary tract infections," Journal of Hospital Infection, vol. 68 , no. 1, pp. 32-38, 2008.

[57] L. Baba-Moussa, H. Ahissou, P. Azokpota et al., "Toxins and adhesion factors associated with Staphylococcus aureus strains isolated from diarrhoeal patients in Benin," African Journal of Biotechnology, vol. 9, no. 5, pp. 604-611, 2010.

[58] V. Peton and Y. Le Loir, "Staphylococcus aureus in veterinary medicine," Infection, Genetics and Evolution, vol. 21, pp. 602-615, 2014.

[59] D. Daka, S. G/silassie, and D. Yihdego, "Antibiotic-resistance Staphylococcus aureus isolated from cow's milk in the Hawassa area, South Ethiopia," Annals of Clinical Microbiology and Antimicrobials, vol. 11, no. 1, p. 26, 2012.

[60] W. Wang, X. Lin, T. Jiang et al., "Prevalence and characterization of Staphylococcus aureus cultured from raw milk taken from dairy cows with mastitis in Beijing, China," Frontiers in Microbiology, vol. 9, p. 1123, 2018.

[61] F. Koksal, H. Yasar, and M. Samasti, "Antibiotic resistance patterns of coagulase-negative staphylococcus strains isolated from blood cultures of septicemic patients in Turkey," Microbiological Research, vol. 164, no. 4, pp. 404-410, 2009.

[62] C. Chiquet, M. Maurin, J. Altayrac et al., "Correlation between clinical data and antibiotic resistance in coagulase-negative Staphylococcus species isolated from 68 patients with acute post-cataract endophthalmitis," Clinical Microbiology and Infection, vol. 21, no. 6, pp. 592.e1-592.e8, 2015.

[63] A.-S. Bonnel, K. Quinque, P. Le Roux, and B. Le Luyer, "Aspergillose nécrosante semi invasive chez un enfant de 14 ans atteint de mucoviscidose," Revue des maladies respiratoires, vol. 23, no. 4, pp. 343-347, 2006.

[64] M. X. Rodrigues, N. C. C. Silva, J. H. Trevilin et al., "Antibiotic resistance and molecular characterization of Staphylococcus species from mastitic milk," African Journal of Microbiology Research, vol. 11, no. 3, pp. 84-91, 2017. 